ТЕОРЕТИЧНІ АСПЕКТИ ВИВЧЕННЯ ОСОБИСТІСНОЇ ЗРІЛОСТІ

\title{
THEORETICAL ASPECTS OF STUDYING PERSONAL MATURITY
}

УДК 159.923

DOI https://doi.org/10.32843/2663-

5208.2020.17.20

\section{Садчікова О.Г.}

аспірантка кафедри психології

Донбаський державний педагогічний університет
Натепер у суспільстві спостерігаються кардинальні зміни на різних рівнях життєдіяльності суспільства. До людини висувається багато вимог щодо ії успішної адаптації в умовах постійних змін: це вміння бачити майбутнє, переконувати й надихати інших, керувати змінами, розробляти i здійснювати стратеаіі. У зв'язку з цим дослідження поняття особистісної зрілості $\epsilon$ актуальним. У статті розглядаються теоретичні підходи до вивчення понять «зрілість» та «особистісна зрілість». Особистість - це конкретна людина, узята в системі їі стійких соціально зумовлених психологічних характеристик, які виявляються в суспільних зв'язках і відношеннях, визначають ї моральні вчинки й мають суттєве значення для неї самої і для оточуючих. Сьогодні існує багато підходів до вивчення поняття «особистісна зрілість». Особистісна зрілість є результатом і ресурсом особистісного розвитку, зумовленим активністю особистості, їі здатністю до самодетермінації, саморегуляиії, потребою в самоактуалізації й саморозвитку, прагненням до смислу як окремих своїх дій, учинків, так і до життєвого смислу загалом. Розглянуто різні підходи до трактування цих понять. Натепер існує багато підходів до вивчення поняття «особистісна зрілість». Проведено теоретичний аналіз досліджень у роботах вітчизняних і закордонних науковців. Аналізуються поняття «особистість» та «особи стісна зрілість». З'ясовано, що рівень особистісної зрілості визначається тим, наскільки особистість є суб'єктом власних трансорормацій, свого саморозвитку. Виявлено критеріі й особливості формування особистісної зрілості особистості. Визначено соціально-психологічні умови, за яких людина може стати особистісно зрілою. Виділено загальні характеристики особистісно зрілої людини, якими $\epsilon$ прагнення до активної соціальної активності, самовдосконалення, творча реалізація, прояв спонтанності, глибокі, але вибіркові взаємини, відповідальне ставлення до життя. Важливим аспектом для особистісно зрілої людини є пошук сенсу свого буття, прагнення бути корисною для інших. Для неї властиві невороже почуття гумору, автономність, здатність до самопізнання й дружніх соціальних стосунків, толерантність.

Ключові слова: особистість, особистісна зрілість, самодетермінація, саморозвиток.
At present, there are radical changes in society at different levels of society. There are many requirements for a person to successfully adapt to constant change, it is the ability to see the future, persuade and inspire others, manage change, develop and implement strategies. In this regard, the study of the concept of personal maturity is relevant. The article considers theoretical approaches to the study of the concept of "maturity" and "personal maturity". Personality is a specific person, taken in the system of its stable socially conditioned psychological characteristics, which are manifested in social ties and relations, determine its moral actions and are essential for itself and for others. Currently, there are many approaches to the study of the concept of "personal maturity". Personal maturity is the result and resource of personal development due to the activity of the individual, his ability to self-determination, self-regulation, the need for self-actualization and self-development, the desire for meaning of individual actions, actions and the meaning of life in general. Different approaches in the interpretation of these concepts are considered. Currently there are many approaches to the study of the concept of "personal maturity".

Theoretical analysis of research in the works of domestic and foreign scientists is carried out. The article analyzes the concepts of "personality" and "personal maturity". It was found that the level of personal maturity is determined by the extent to which the individual is the subject of their own transformations, their self-development. Criteria and features of formation of personal maturity of the person are revealed. The socio-psychological conditions under which a person can become personally mature are determined. The general characteristics of a personally mature person are highlighted, which are the desire for active social activity, self-improvement, creative realization, spontaneity, deep but selective attitudes, responsible attitude to life. An important aspect for a personally mature person is to find the meaning of his life, to be useful to others. It is characterized by a hostile sense of humor, autonomy, the ability to self-knowledge, tolerance and friendly social relations.

Key words: specialty, specialty maturity, selfdetermination, self-development.
Постановка проблеми. Характерною особливістю сучасного світу $€$ наявність кардинальних змін практично в усіх сферах життя: від зміни біологічних ресурсів (зміна флори і фауни, геологічної специфіки планети тощо) до стратегічних соціально-економічних перетворень у суспільствах і державах. Як представники природничих наук зараз активно вивчають наявний стан планети і її зміни, так і представникам наук про людину необхідно посилене дослідження самої людини в сучасному світі: особливостей ії свідомості, установок, рівня, перспектив розвитку тощо.

У зв'язку з цим вивчення феномена особистісної зрілості в цей конкретно-історичний період $€$ актуальним. У свою чергу, проблема зрілості $є$ складником проблем розвитку людської особистості і свідомості.

Сьогодні в суспільстві відбуваються реформаційні процеси, які з особливою гостротою 
висувають вимоги до людини як до соціально зрілої, повноцінної особистості, визнають вирішальною роль суб'єкта, який здатний здійснювати соціальні зміни й змінюватися сам. Чим прогресивнішим є суспільство, тим досконалішу, більш зрілої особистості воно потребує й більш зрілу особистість формує для здійснення своїх завдань. 3 іншого боку, чим вища соціальна зрілість людей, тим швидше рухається суспільство в прогресивному розвитку.

У період суспільних трансформацій об'єктом спеціального вивчення мають бути психологічні властивості суб'єкта, який оволодіває ефективними стратегіями саморозвитку, прагне змін і вміє ними керувати, долає особистісні деформації, здатний до мобілізації власних ресурсів та активізації свого потенціалу. Особливу увагу науковці приділяють причинам та умовам досягнення людиною якісно нового рівня особистісної зрілості. Високий рівень особистісної зрілості дасть змогу людині усвідомити процеси самопізнання, саморозвитку й самореалізації як життєві цінності, створювати умови для самовдосконалення та самовиховання в життєдіяльності, пізнавати, актуалізувати, творчо формувати свою індивідуальність. Людина мусить у розвитку ставити нові завдання, які відкривають нові можливості для нових життєвих виборів особистості, для нових кроків до самоздійснення.

Наукове зацікавлення викликають соціально-психологічні властивості суб'єкта, який прагне до самопізнання, здатний до самоуправління й може не лише не розгубитися в час суспільних трансформацій, а й зробити відповідальний вибір івплинути на напрям цих перетворень. Спеціалісти з питань лідерства і брендингу переконані, що вміти бачити майбутнє, переконувати й надихати інших, керувати змінами, а також розробляти і здійснювати стратегії може людина, яка характеризується як зріла, зокрема особистісно зріла.

Аналіз останніх досліджень і публікацій. Проблема особистісної зрілості була предметом вивчення як зарубіжних, так і вітчизняних науковців (Б.Г. Ананьєв, Л.І. Анциферова, М.Й. Боришевський, Ю.З. Гільбух, Г.А. Дьоміна, Е. Еріксон, Д.О. Леонтьєв, Л.П. Овсянецька, Г. Олпорт, Ф. Перлз, Л.М. Потапчук, А.А. Реан, Т.М. Титаренко, О.С. Штепа, П.М. Якобсон та ін.). Дослідники відмічають, що детермінантами особистісної зрілості $\epsilon$ психологічна й соціальна зрілість особистості (А.А. Реан, О.С. Штепа, П.М. Якобсон та ін.), які стали предметом спеціального розгляду багатьох учених (М.В. Драганов, С.Н. Іконнікова, В.Т. Лісовський, Х. Томе, К.К. Платонов, Л.П. Овсянецька, В.В. Радул, О.Б. Старовойтенко, Д.І. Фельдштейн, П.М. Якобсон та ін.). Особистісна зрілість характеризується стій- кими ціннісними орієнтаціями (А.Г. Здравомислов, В.А. Ядов), відчуттям ідентичності (Е. Еріксон, Є.В. Чорний), визначається успішністю процесу самоактуалізації (Ю.Г. Долінська, І.Я. Шемелюк) тощо.

Постановка завдання. Мета дослідження - провести теоретичний аналіз особистісної зрілості в концепті проблеми «особистісної зрілості» в психологічних дослідженнях.

Виклад основного матеріалу дослідження. Поняття «особистість» $€$ не суто психологічне, вивчається воно всіма суспільними науками: філософією, соціологією, етикою, педагогікою тощо. Зрозуміти природу особистості можна через літературу, музику, образотворче мистецтво. Особистість відіграє важливу роль у вирішенні політичних, економічних, наукових, культурних, технічних проблем, загалом у піднесенні рівня людського буття.

Категорія особистості посідає в сучасних наукових дослідженнях і в суспільній свідомості одне із центральних місць. Завдяки категорії особистості постають можливості для цілісного підходу, системного аналізу та синтезу психологічних функцій, процесів, станів, властивостей людини.

у психологічній науці не існує загальноприйнятого визначення природи особистості. Період активного наукового вивчення проблем особистості можна умовно поділити на два етапи. Перший охоплює час з кінця XIX до середини XX ст. і приблизно збігається з періодом становлення класичної психології. У цей час сформульовані фундаментальні положення про особистість, закладені основні напрями дослідження психологічних особливостей особистості. Другий період досліджень проблем особистості розпочався в другій половині XX ст.

На думку Б.Г. Ананьєва, неможливо вирішити проблему вивчення феномена особистості зусиллями будь-якої однієї науки. Для цього є потреба в комплексно-інтегрованому підході до його вивчення, розробленні цілісної системи теоретичного та практичного людинознавства.

Узагальнюючи відомі підходи, можемо зробити висновок, що особистість - це конкретна людина, узята в системі її стійких соціально зумовлених психологічних характеристик, які можна виявити в суспільних зв'язках і відношеннях, а також визначають її моральні вчинки й мають вагоме значення для неї самої й для оточуючих.

Г. Олпорт був першим, хто ввів у психологію уявлення про зрілу особистість, помітивши, що психоаналіз ніколи не розглядає дорослу людину як дійсно дорослу. Перший критерій - різноманітність автономних інтересів, розширення «Я». Другий - самосвідомість, 
самооб'єктивація. Сюди ж він зараховує таку характеристику, як почуття гумору, яка, за експериментальними даними, найкраще корелює зі знанням себе. Третій критерій - філософія життя. Зріла особистість має свій світогляд, на відміну від особистості незрілої. У більш пізніх роботах він розширює й доповнює перелік цих критеріїв, описуючи вже 6 основнихпараметрів зрілої особистості, які вбирають у себе перші три. По-перше, психологічно зріла людина має широкі межі Я. По-друге, їй притаманна здатність до близьких міжособистісних взаємин. Співчуття відбивається в здатності бути терпимим до відмінностей у цінностях та установках між собою й іншими людьми. Третій критерій - відсутність великих емоційних бар'єрів і проблем, гарне самоприйняття. Зрілі люди здатні спокійно ставитися до власних недоліків і зовнішніх труднощів, не реагуючи на них емоційними зривами; вони вміють справлятися з власними станами, висловлюючи свої емоції й почуття, вони зважають на те, як це вплине на інших. Четвертий критерій - зріла людина демонструє реалістичне сприйняття, а також реалістичні домагання. Вона бачить речі такими, якими вони $є$, а не такими, якими вона хотіла б їх бачити. По-п'яте, зріла людина демонструє здатність до самопізнання й філософського почуття гумору - гумору, спрямованого на самого себе. По-шосте, зріла людина має цільну життєву філософію. Який зміст цієї філософії, принципової ролі не грає, найкращої філософії не існує [10, с. 85].

У розвитку особистості К. Юнг виділив стадію індивідуації, яку людина може досягти духовно розвиваючись. Індивідуацією можна назвати розвиток самості, тобто становлення людиною істотою цілісною, єдиною, «самою собою». К. Юнг назвав якості зрілої, здорової особистості. На його думку, це бути людиною творчою, самодосконалою. Саме ці риси притаманні людині й мають свої коріння з колективного несвідомого [4, с. 45].

Аналізуючи біографії видатних зрілих особистостей, А. Маслоу звернув увагу на такі загальні риси: прийняття себе, інших, природи, ефективне сприйняття реальності й комфортні взаємини $з$ нею; креативність; спонтанність; незалежність від культури й оточення; зосередженість на проблемі; відстороненість; безмежні обрії; соціальне почуття; постійна свіжість оцінок; глибокі, але виборчі соціальні взаємини; демократичний характер; моральна переконаність; невороже почуття гумору. Вільна особистість, яка спирається на себе як на істоту цілісно природну, прислухається до себе, може точно й повно відображати свої внутрішні процеси, має «тенденцію до актуалізації», яка діє на повну силу. Саме ця дія дає змогу людині рухатися, розвиваючи власну зрілість, що сприяє більш повноцінному життю [9, с. 51].
В. Франкл уважав, що саме самотрансценденція $€$ найважливішою якістю людини загалом, що приведе особистість до автентичності. Автентичність, за В. Франклом, - підсумок знаходження смислу буття, що приведе до знаходження зрілості [7, с. 121].

К. Роджерс пов'язує поняття «повноцінно функціонуюча особистість» та «гарне життя». Поняття «повноцінно функціонуюча особистість» він використовує для зображення здорової, зрілої особистості. Для розуміння «гарного життя» К. Роджерс використовує такі вислови: захоплююче, значиме, таке, що збагачує, винагороджує, кидає виклик. Людина, що живе «гарним життям», - це людина творча, яка живе більш повноцінно, з більшим проявом почуттів, бо вона має впевненість у собі, коли зустрічається з різноманітними проявами сьогодення [11, с. 78-79].

С.Л. Братченко й М.Р. Миронова посилаються на концепцію К. Роджерса, розглядаючи поняття «зріла особистість». Автори вважають, що для зрілої особистості притаманні цілеспрямованість, самостійність, динамічність, цілісність, конструктивність, індивідуальність. Рівень розвитку цих якостей залежить від певних умов: передусім того, які в особистості сформуються взаємини із зовнішнім світом і внутрішнім світом, оточуючими людьми. На думку дослідників, якщо є необхідні умови, то в людині може актуалізуватися процес саморозвитку. Природним наслідком процесу саморозвитку буде розвиток особистісної зрілості особистості. С.Л. Братченко й М.Р. Миронова вважають, що спрямованість, динаміка, утримування особистісних змін можуть бути критеріями особистісного розвитку. Критерії особистісного зростання автори розділяють на інтраперсональні й інтерперсональні [5, с. 56].

Дослідники неодноразово підкреслювали, що особистісна зрілість не $є$ віковою рисою. Так, Б.Г. Ананьєв робив акцент на тому, що поняття дорослості й зрілості не $є$ тотожні. О.О. Бодальов розмежував дорослість і зрілість [4, с. 34]. На думку К.О. Абульханової й Т.М. Березіної, зрілість - це результати, які особистість досягає завдяки певному способу життя [1, с. 15-16]. Е. Еріксон уважає, що взаємозв'язок між зрілістю як якості особистості та дорослістю як вікового етапу дуже слабкий. Морально зрілою особистістю може бути індивід, який не досяг фізичної дорослості, й навпаки [12, с. 32].

У роботах психологів близького зарубіжжя та українських психологів (К.О. Абульханова, Т.М. Березина, Д.О. Леонтьєв, О.Р. Калітієвська, О.С. Штепа, А.О. Реан та ін.) неодноразово підкреслювався зв'язок особистісної зрілості з такими особистісними рисами, як активність особистості, їі свобода, відповідальність. 
К.О. Абульханова й Т.М. Березіна вважають, що зрілість можна визначити своєчасністю особистості як знаходження свого способу життя. У кожної людини є її власний ритм життя, часові потенціали, які забезпечують основу для здатності особистості опановувати свої природні психічні можливості й особливості, перетворити їх у ресурси своєї активності. Надалі свідомо та гармонійно використовуючи свою активність у вигляді самовираження, самореалізації у формах життєдіяльності, спілкуванні, людина може стати більш зрілою [1, с. 67].

Д.О. Леонтьєв, О.Р. Калітієвська і співавтори також виділяють головну якість, що властива зрілій особистості, - здатність до самодетермінації. Самодетермінація - можливість діяти згідно з власними ціннісно-значеннєвими орієнтаціями та довгостроковим інтересом, не піддаючись зовнішнім тискам. Здатність до самодетермінації виникає в ході індивідуального розвитку на основі інтеграції свободи й відповідальності [12, с. 56].

О.С. Штепа пов'язує особистісну зрілість із розв'язанням криз, а також із самодетермінацією особистості. Дослідниця в роботі визначає, що процес самостійно пережитої людиною в зрілому віці ненормативної кризи ідентичності призведе до розвитку особистісної зрілості. О.С. Штепою виділено десять експлікованих рис зрілої особистості: відповідальність, глибинність переживань, синергічність, автономність, контактність, самоприйняття, креативність, толерантність, децентрацію, життєву філософію [13, с. 53].

Декілька основних ліній розвитку виділяе С.Д. Максименко. На його думку, саме ці лінії сприяють появі гармонійної особистості, що цілком відповідає основним рисам особистісної зрілості. Автор виділяє такі лінії розвитку: народження особистості, яке пов'язане з появою суб'єкта; лінію розвитку інтеграції особистості, що визначає особистість не тільки як суб'єкта власної поведінки, а і як суб'єкта свого внутрішнього світу; лінію почуття причетності й інтринсивної мотивації як умову формування інтернального локусу контролю; лінію розвитку саморегуляції й сенсу життя [8, с. 65].

Н.М. Дідик на основі проведеного аналізу понять особистісної зрілості в психологічній науці виявила, що феномен особистісної зрілості можна охарактеризувати такими рисами, як здатність до вчинку; самоприйняття; самоактуалізація; суб'єктність, трансценденція; відповідальність, інтернальний локус контролю; саморегуляція; соціабельність; креативність; самостійність; філософське почуття гумору; інтелектуальність; автентичність; нонконформізм; моральність; психічне здоров'я $[7$, c. 43].
Натепер представлено багато точок зору з вивчення природи зрілості особистості:

1. Зріла особистість як психологічно здорова особистість. О.В. Хухлаєва психологічне здоров'я визначає як динамічну сукупність психічних властивостей, які забезпечують гармонічне поєднання між внутрішніми якостями людини та між людиною й суспільством. До поняття психологічно здорової особистості також входить здатність до повноцінного розвитку та функціонування людини в процесі своєї життєдіяльності [3, с. 19].

2. Зріла особистість як психологічно благополучна особистість. Виділяють два підходи в дослідженні психологічного благополуччя гедоністичний та евдемоністичний. До гедоністичних теорій належать ті, які благополуччя описують у системі незадоволеності/задоволеності (Н. Бредбурн, М. Аргайл, Е. Дінер). Евдемоністичний підхід ґрунтується на твердженні, що особистісне зростання - найголовніша й необхідніша умова благополуччя (К. Ріфф, А. Вотермен, М. Селігман Р. Райан) [7, с. 25]. Існують концепції, які прагнуть об'єднати обидва підходи.

3. Зріла особистість як набір певних особистісних властивостей. Після проведеного аналізу досліджень зарубіжних і вітчизняних авторів виділені характеристики, які $є$ складниками зрілої особистості: високий рівень рефлексії, наявність стійкої єдності особистісних рис, реалістичність, функціональна автономність, уміння розділяти ідеальні та реальні цілі, гнучкість поведінки й самоконтроль, стійкі й несуперечливі ціннісні орієнтації, розвинене почуття відповідальності, потреба в пошуку сенсу життя, здатність до психологічної близькості з іншою людиною, толерантність, спроможність активної участі в житті соціуму, ефективне застосування своїх потенціалу та знань, уміння конструктивно вирішувати життєві проблеми тощо [3, с. 75].

Виходячи з вищевикладеного, можемо зазначити, що особистісна зрілість $є$ підсумком і ресурсом особистісного розвитку особистості. Цей процес відбувається завдяки активності особистості, її здатності до самодетермінації, саморегуляції. В особистості, що розвивається, є нагальна потреба в самоактуалізації й саморозвитку, прагнення до пошуку смислу як окремих своїх дій, учинків, так і до життевого смислу загалом. Саме спроможністю особистості бути суб'єктом власних трансформацій, свого саморозвитку визначається ступінь особистісної зрілості.

Висновки 3 проведеного дослідження. Отже, сьогодні існує багатопідходівдовивчення поняття «особистісна зрілість». У кожному підході науковці вивчають категорії, те, які, на їхню думку, найважливіші складники цього поняття. Не має єдиної концепції дослідження цього 
поняття. Але, виходячи з розглянутих теорій, можемо виділити загальні характеристики особистісно зрілої людини як людини, яка прагне до активної соціальної активності, самовдосконалення, творчої реалізації, проявів спонтанності, глибоких, але виборчих відносин, відповідального ставлення до життя. Також для особистісно зрілої людини важливо зрозуміти сенс свого буття й бути корисною для інших, їй властиві автономність, толерантність, здатність до самопізнання та дружніх соціальних стосунків, невороже почуття гумору.

\section{ЛІТЕРАТУРА:}

1. Абульханова К.А., Березина Т.Н. Время личности и время жизни. Санкт-Петербург : Алетейя, 2001. 304 c.

2. Абульханова-Славская К.А. Стратегия жизни. Москва : Мысль, 1991. 298 с.

3. Ананьев Б.Г. Психология и проблемы человекознания. Москва : Институт практической психологи ; Воронеж : НПО «МОДЭК», 1996. 384 с.

4. Бодалёв А.А. Вершина в развитии взрослого человека: характеристики и условия достижения. Москва : Флинта : Наука, 1998. 168 с.
5. Братченко С.Л., Миронова М.Р. Личностный рост и его критерии. Психологические проблемы самореализации личности / под ред. А.А. Крылова, Л.А. Коростылевой. Санкт-Петербург : Изд-во С.-Петерб. ун-та, 1997. С. 56.

6. Зрелость как этап и как качество в психическом развитии человека. Гамезо М.В., Петрова Е.A., Орлова Л.М. Возрастная и педагогическая психология. Москва : Педагогическое общество России, 2003. 324 C.

7. Максименко С.Д. Генезис существования личности. Киев : Издательство ООО «КММ», 2006. 240 с.

8. Маслоу А. Мотивация и личность. СанктПетербург : Евразия, 1999. 478 с.

9. Олпорт Г. Становление личности: избранные труды. Москва : Смысл, 2002. 462 с.

10. Роджерс К.Р. Взгляд на психотерапию. Становление человека. Москва : Прогресс-Универс, 1994. $480 \mathrm{c}$.

11. Смысл, адаптация и самодетерминация у подростков / Е.Р. Калитиевская, Д.А. Леонтьев, Е.Н. Осин, И.И. Бородкина. Вопросы психологии. 2007. № 2. 125 C.

12. Штепа О.С. Особистісна зрілість: Модель. Опитувальник. Тренінг : монографрія. Львів : Видавничий центр ЛНУ імені Івана Франка, 2008. 210 с. 